\title{
アルミニウム合金と $\mathrm{S} 25 \mathrm{C}$ 炭素鋼の摩擦圧接性に及ぼす 金属間化合物の影響十
}

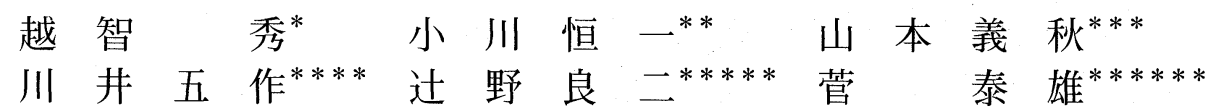 \\ Effect of Intermetallic Compounds on Friction Weldability of \\ Aluminum Alloys to S25C Carbon Steel
}

\author{
by

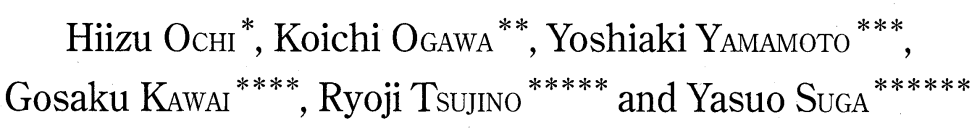

Aluminum alloys to S25C carbon steel were friction welded, and the friction weldability and intermetallic formations at the weld interface of joints were investigated. Joints of A1050, A5052, A6061 and A6063 to S25C showed goodweldability, and A5056/S25C joint was somewhat poor than former one. An intermetallic compound of $\mathrm{Al}_{13} \mathrm{Fe}_{4} \mathrm{was}$ formed at the weld interface of A5056/S25C and A6061/S25C joints, and their intermetallic formations were tend to increase with friction pressure, friction time and rotation speed. The joint strength of these joints was high when thin instermetallic conpound layer was formed under high upset pressure. Somewhat poor-weldability of A5056/S25C joint compared with A6061/S25C joint seemed a cause of the intermetallic formation accelated by high content of magnesium in A5056. Joints of A2011, A2017, A2024 and A7075 to S25C showed poor-weldability. Brittle intermetallic compounds of $\mathrm{CuAl}_{2}$ and $\mathrm{Al}_{7} \mathrm{Cu}_{2} \mathrm{Fe}$ were formed at the weld interface of $\mathrm{A} 2011 / \mathrm{S} 25 \mathrm{C}$ joint containing a copper.

Key words : Friction welding, Aluminum alloy, S25C carbon steel, Friction weldability, Intermetallic compound

\section{1 緒言}

近年, 部品の軽量化, コスト削減, 省資源, 省エネル ギー等の観点から，アルミニウム合金と鋼の異材継手が 注目されている。従来, この種の継手は接合界面に脆弱 な金属間化合物が形成されるため，良好な接合は困難で あるとされてきた.1)しかしながら，アルミニウム合金の 種類は多様であることから, その添加元素の種類や量に 応じて界面に形成される金属間化合物は異なり，また鋼 との接合性も異なることが予想される。これまで著者ら は，広く一般に市販されている 9 種類のアルミニウム合 金管とSUS304 ステンレス鋼管との摩擦圧接を行い，そ れらの接合性について検討した 2) その結果, マグネシウ ム等の添加元素の含有量の少ない 6000 系合金は, 純ア ルミニウムと同様，ステンレス鋼との接合性が良好であ るが，マグネシウムを多く含有する 5000 系合金は 6000 系合金に比べて接合性がやや劣る。さらに，銅を多く含 有する 2000 系およびA7075 合金は接合性が悪いことが わかった。このような接合性の差異は，界面に形成され
る金属間化合物の種類と量に左右されるものと推測され る.ところで，管材は母材の座屈のため高い圧力を負荷 し難いなどの問題点があるが，接合面内における半径方 向の摩擦速度の差異が小さいことや，界面の不純物を排 出しやすい等の利点があり, 圧接界面の様相を調べやす いと考えられる。しかしながら，実際にはばりが外側と 内側に排出されて界面層が薄くなり，金属間化合物の同 定や様相の観察が困難である。そこで本研究では，9種 類のアルミニウム合金と $\mathrm{S} 25 \mathrm{C}$ 炭素鋼の中実摩擦圧接継 手を作製し，その接合性を調べた。さらに，接合性の異 なる代表的な 3 種の組合せ材を選定し，圧力，時間およ び回転数などの圧接条件因子が，界面での金属間化合物 の形成状態に及ぼす影響について検討した。

\section{2 実 験 方 法}

本研究で用いた供試材は，1050-H14，2011-T3，2017T4, 2024-T4, 5052-H34, 5056-H34, 6061-T6, 6063-T5 および 7075-T6 アルミニウム合金と S25C 炭素鋼である. これらの化学成分と機械的性質を Table I およびTable II

\footnotetext{
$\dagger$ 原稿受理 平成 15 年 5 月 26 日 Received May 26, 2003

* 大阪工業大学共同研究センター

** 正 会 員 大阪府立大学総合科学部総合科学科 ７599-8531 堺市学園町, College of Integ. Arts and Sci., Osaka Pref. Univ., Gakuen-cho, Sakai, $599-8531$

*** 正 会員 攝南大学工学部機械工学科 $\overline{7} 572-8508$. 寝屋川市池田中町, Faculty of Eng., Setsunan Univ., Ikedanaka-machi, Neyagawa, $572-8508$

$* * * *$ 大阪産業大学工学部機械工学科 $=574-8530$ 大東市中垣内, Faculty of Eng., Osaka Sangyo Univ., Nakagaito, Daito, 574-8530

***** 大阪工業大学短期大学部機械工学科 ₹535-8585 大阪市旭区大宮, Dept. of Mech. Eng., Jr. College, Osaka Inst. Tech., Asahi-ku, Osaka 535-8585

$* * * * * * \quad$ 慶應義塾大学理工学部機械工学科 $\quad$ T223-8522 横浜市港北区日吉, Faculty of Sci. and Tech., Keio Univ., Kohoku-ku, Yokohama, 223-8522
} 
Table I. Chemical compositions of base material (mass \%).

\begin{tabular}{|l|c|c|c|c|c|c|c|c|c|c|c|c|}
\hline \multicolumn{1}{|c|}{ Material } & $\mathrm{Si}$ & $\mathrm{Fe}$ & $\mathrm{Cu}$ & $\mathrm{Mn}$ & $\mathrm{Mg}$ & $\mathrm{Cr}$ & $\mathrm{Zn}$ & $\mathrm{Ti}$ & $\mathrm{Ti}+\mathrm{Zr}$ & $\mathrm{Bi}$ & $\mathrm{Pb}$ & $\mathrm{Al}$ \\
\hline A1050-H14 & 0.13 & 0.13 & 0.00 & 0.00 & 0.01 & 0.00 & 0.00 & 0.01 & - & - & - & $\mathrm{Bal}$ \\
A2011-T3 & 0.10 & 0.18 & 5.50 & - & - & - & 0.00 & - & - & 0.50 & 0.50 & $\mathrm{Bal}$ \\
A2017-T4 & 0.37 & 0.31 & 4.30 & 0.50 & 0.60 & 0.02 & 0.10 & 0.02 & 0.02 & - & - & $\mathrm{Bal}$ \\
A2024-T4 & 0.20 & 0.25 & 4.40 & 0.60 & 1.40 & 0.01 & 0.10 & 0.02 & 0.02 & - & - & $\mathrm{Bal}$ \\
A5052-H34 & 0.10 & 0.14 & 0.01 & 0.03 & 2.46 & 0.20 & 0.01 & 0.01 & - & - & - & $\mathrm{Bal}$ \\
A5056-H34 & 0.06 & 0.13 & 0.01 & 0.07 & 4.20 & 0.05 & 0.01 & 0.01 & - & - & - & $\mathrm{Bal}$ \\
A6061-T6 & 0.59 & 0.16 & 0.20 & 0.01 & 0.95 & 0.06 & 0.01 & 0.01 & - & - & - & $\mathrm{Bal}$ \\
A6063-T5 & 0.43 & 0.13 & 0.01 & 0.00 & 0.51 & 0.00 & 0.00 & 0.00 & - & - & - & $\mathrm{Bal}$ \\
A7075-T6 & 0.11 & 0.25 & 1.70 & 0.09 & 2.40 & 0.20 & 5.60 & 0.02 & 0.03 & - & - & $\mathrm{Bal}$ \\
\hline
\end{tabular}

\begin{tabular}{|l|c|c|c|c|c|c|c|c|c|}
\hline Material & $\mathrm{Si}$ & $\mathrm{Fe}$ & $\mathrm{Cu}$ & $\mathrm{Mn}$ & $\mathrm{Cr}$ & $\mathrm{C}$ & $\mathrm{P}$ & $\mathrm{S}$ & $\mathrm{Ni}$ \\
\hline S25C & 0.22 & $\mathrm{Bal}$ & 0.08 & 0.40 & 0.14 & 0.22 & 0.017 & 0.014 & 0.04 \\
\hline
\end{tabular}

Table II . Mechanical properties of base material.

\begin{tabular}{|l|c|c|c|c|}
\hline Material & $\begin{array}{c}\text { Proof } \\
\text { stress } \\
\sigma_{0.2} \\
(\mathrm{MPa})\end{array}$ & $\begin{array}{c}\text { Tensile } \\
\text { strength } \\
\sigma_{\mathrm{B}} \\
(\mathrm{MPa})\end{array}$ & $\begin{array}{c}\text { Elongation } \\
\varepsilon(\%)\end{array}$ & $\begin{array}{c}\text { Hardness } \\
\mathrm{HV}\end{array}$ \\
\hline A1050-H14 & 97 & 98 & 22.0 & 37 \\
A2011-T3 & 318 & 399 & 16.2 & 137 \\
A2017-T4 & 276 & 446 & 20.4 & 145 \\
A2024-T4 & 429 & 578 & 13.0 & 146 \\
A5052-H34 & 254 & 259 & 19.0 & 94 \\
A5056-H34 & 223 & 332 & 22.2 & 100 \\
A6061-T6 & 284 & 301 & 18.8 & 110 \\
A6063-T5 & 125 & 160 & 31.0 & 64 \\
A7075-T6 & 597 & 646 & 19.6 & 190 \\
S25C & $282 *$ & 465 & 30.1 & 156 \\
\hline
\end{tabular}

*: Yield stress

に示す．直径 $16 \mathrm{~mm}$ で供給されたこれらの供試材を全長 $80 \mathrm{~mm}$ に切断した後, 圧接端面側から長さ $20 \mathrm{~mm}$ だけ直 径 $14 \mathrm{~mm}$ に機械加工し, 圧接端面は旋削のままで（中心 線平均粗さ約 $2 \mu \mathrm{m}$ ), 圧接直前にアセトン洗浄を施し圧 接に供した。摩擦圧接は, 摩擦圧力 $\mathrm{P}_{1}(\mathrm{MPa})$, アプセッ 卜圧力 $\mathrm{P}_{2}(\mathrm{MPa})$, 摩擦時間 $\mathrm{t}_{1}(\mathrm{~s})$ および回転数 $\mathrm{N}\left(\mathrm{s}^{-1}\right)$ の 4 つの条件因子を変化させて, ブレーキ式摩擦圧接機 を用いて行った。圧接後, 継手からばりを取り除いた平 滑試験片（平衡部直径 $13.5 \mathrm{~mm}$ ）を用いて引張試験を行 い引張強さ $\sigma_{\mathrm{B}}(\mathrm{MPa})$ を求めた。 なお, 継手性能は各ア ルミニウム合金の母材強度が大きく異なることから, 継 手強度をアルミニウム合金母材の引張強さで除した継手 効率 $\psi(\%)$ で評価した.

ついで，接合性の大きく異なる 3 種の継手（A2011/ S25C，A5056/S25C およびA6061/S25C）を選定し，こ れらの摩擦面の X 線回折を行い，接合界面に形成された 金属間化合物の同定を行った。なお， X 線回折には，圧 接時にアプセット圧力を負荷せずに両母材を引き離して 作製した試料を供した。さらに, 種々の条件で圧接した これらの継手断面の SEM 観察および EPMA 分析を行 い，圧接条件と金属間化合物層の形成状態の関係を調べ た. 金属間化合物の形成状態に及ぼす圧接条件因子とし ては, 圧力, 時間および回転数の 3 因子を取りあげた。 まず, 摩擦圧力 $20 \mathrm{MPa}$, 摩擦時間 $3 \mathrm{~s}$, 回転数 $50.0 \mathrm{~s}^{-1}$ を
基本となる圧接条件として, 摩擦圧力を $20,40,60$ お よび $80 \mathrm{MPa}$ ，摩擦時間を 1,3 および $5 \mathrm{~s}$ ，回転数を 33.3 , 50.0 および $66.7 \mathrm{~s}^{-1}$ にそれぞれ変化させた 8 条件で継手を 作製した．なお，圧力の影響を簡潔にするために，この 場合のアプセット圧力は摩擦圧力と同一にした。 ついで, 3 種のいずれの継手の場合にも金属間化合物層が比較的 厚く形成された圧接条件，すなわち摩擦圧力 $40 \mathrm{MPa}$ ，摩 擦時間 $3 \mathrm{~s}$, 回転数 $50.0 \mathrm{~s}^{-1}$ (アプセット圧力 $40 \mathrm{MPa}$ ）を 基本として，アプセット圧力のみを $90 \mathrm{MPa}$ および 140 $\mathrm{MPa}$ に変化させて継手を作製し，アプセット圧力の負荷 による化合物の排出について調べた。 さらに，最適摩擦 圧接条件で作製した継手に打ける化合物の形成状態とも 比較を行った。

\section{3 結 果と考 察}

\section{$3 \cdot 1$ 各アルミニウム合金と $\mathrm{S25C}$ との摩擦圧接性}

各アルミニウム合金と S $25 \mathrm{C}$ の継手を広範囲な圧接条 件で作製し, 継手効率を求めた。A2011，A5056 および A6061 の場合の結果の一部を Fig. 1 〜 3 に示す. A2011 の場合には全般的に強度が低く接合性は悪い。なお，こ れらの継手はいずれも圧接界面で破断した. A5056の場 合は，広範囲な圧接条件で同程度の最大強度を持つ継手 が得られるが，最大継手効率は約 $50 \%$ で接合性はやや劣 る。なお，これら継手はいずれも圧接界面で破断した。 A6061 の場合には，アプセット圧力が高くなるほど継手 効率が高くなる傾向を示し, 最大継手効率は $95 \%$ であり

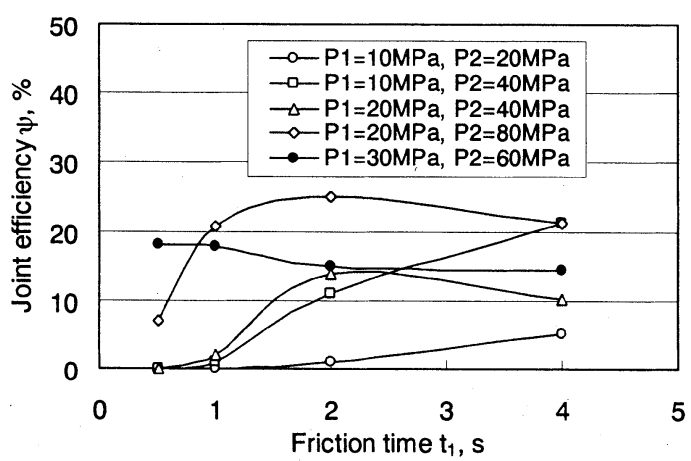

Fig. 1. Changes in joint efficiencies of A2011/S25C with friction time. 


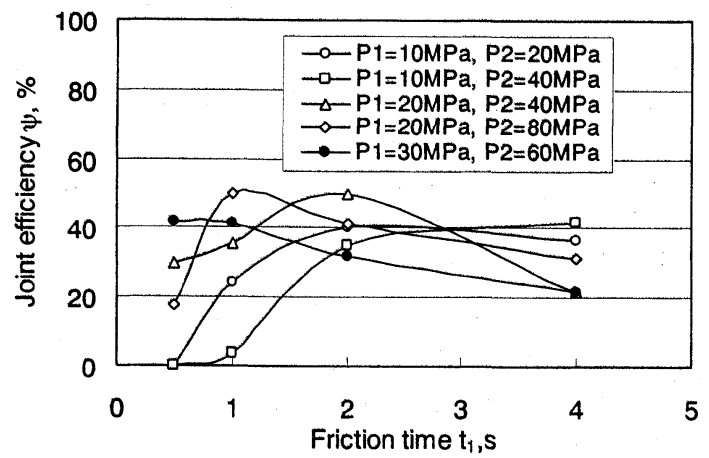

Fig. 2. Changes in joint efficiencies of A5056/S25C with friction time.

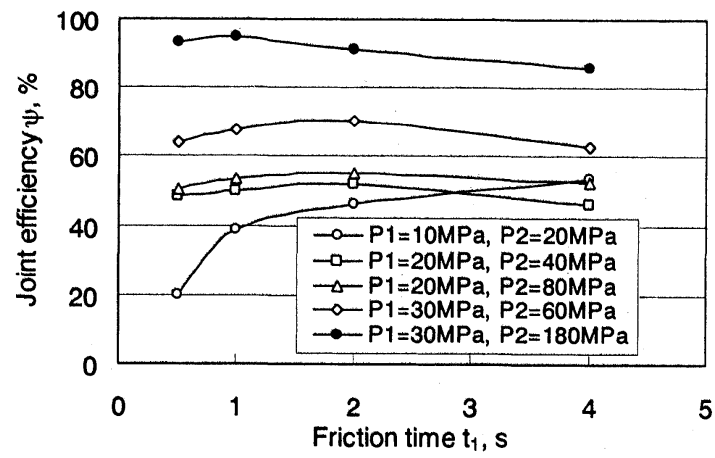

Fig. 3. Changes in joint efficiencies of A6061/S25C with friction time.

接合性は良好である。な抢，この場合の継手は圧接界面 と A6061 側の両方で混合破断した。最大継手効率が 100\% 以下であるのは，A6061-T6のような熱処理型合金 は熱影響部が軟化するためである.

以上のように，9種のアルミニウム合金と $\mathrm{S} 25 \mathrm{C}$ との 摩擦圧接を行い，それら継手の最大引張強さおよび最大 継手効率を求めた。その結果を Fig. 4 に示す．A1050 （純アルミニウム系）打よび 6000 系合金（Al-Mg-Si 系） の場合には，最大継手効率は $90 \%$ 以上であり接合性は良 好である. 5000 系合金（Al-Mg 系）の場合には，A5052 の場合の最大継手効率は $75 \%$ と高く，接合性は比較的良 好といえる。一方，A5056 の場合には，最大継手効率が $50 \%$ 程度であり中程度の接合性といえる。2000 系合金 （Al-Cu 系）およびA7075（Al-Zn-Mg-Cu 系）の場合には，

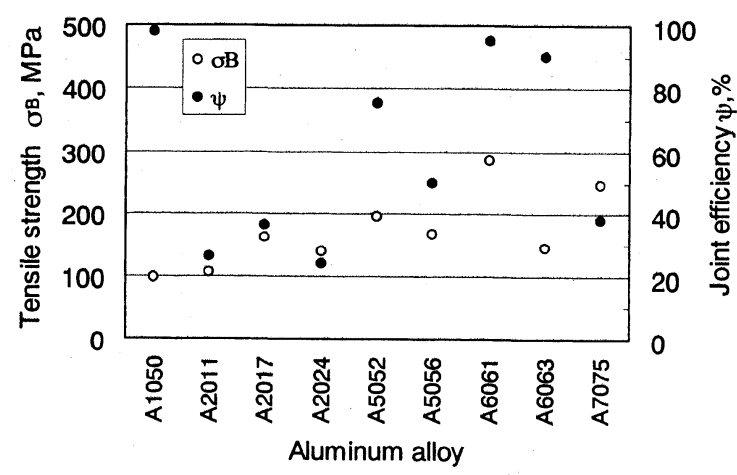

Fig. 4. Maximum tensile strength and joint efficiencies of various aluminum alloy to $\mathrm{S} 25 \mathrm{C}$ joints.
最大継手効率は $40 \%$ 以下と低く接合性は悪い.

ところで，著者らがこれまでに調べたこれら9種のア ルミニウム合金管と SUS304 ステンレス鋼管との最大継 手効率は, A1050, A2011, A2017, A2024, A5052, A5056，A6061，A6063 およびA7075 の場合乥れぞれ 91， $26 ， 39 ， 32 ， 71 ， 60 ， 79 ， 97$ および $37 \%$ であり，2)兄の接 合性は本実験の場合とほぼ同じ傾向を示している。この ように，アルミニウム合金の種類によって摩擦圧接性を 区別することが可能であることから，接合性の差異はア ルミニウム合金中の添加元素に左右されると推測される. すなわち, 添加元素の種類や量によって界面に形成され る金属間化合物の種類や析出量が異なり，接合性も異な ったと考えられる？そこで次に，9種類のアルミニウム 合金の中から，S25C との接合性の良好な A6061，中程 度の接合性を有する A5056，そして接合性の悪いA2011 を選び，これらの接合界面における金属間化合物の形成 状態について検討した。

\section{$3 \cdot 2 \mathrm{X}$ 線回折による摩擦面の金属間化合物の同定}

摩擦圧力 $20 \mathrm{MPa}$ および回転数 $50.0 \mathrm{~s}^{-1}$ の条件で A2011, A5056 およびA6061 と S25C とを 3 秒間摩擦させた後に， 固定側母材を瞬時に後退させて引き離した。笛して，両 母材の摩擦面の X線回折を行い，析出した金属間化合物 の同定を行った。各摩擦面のX 線回折図を Fig. 5 に示 す. $\mathrm{A} 5056$ およよび $\mathrm{A} 6061$ の場合にはいずれも $\mathrm{Al}_{13} \mathrm{Fe}_{4}$ に基 づく回折線が認められるが，光の強度はA5056 の方が

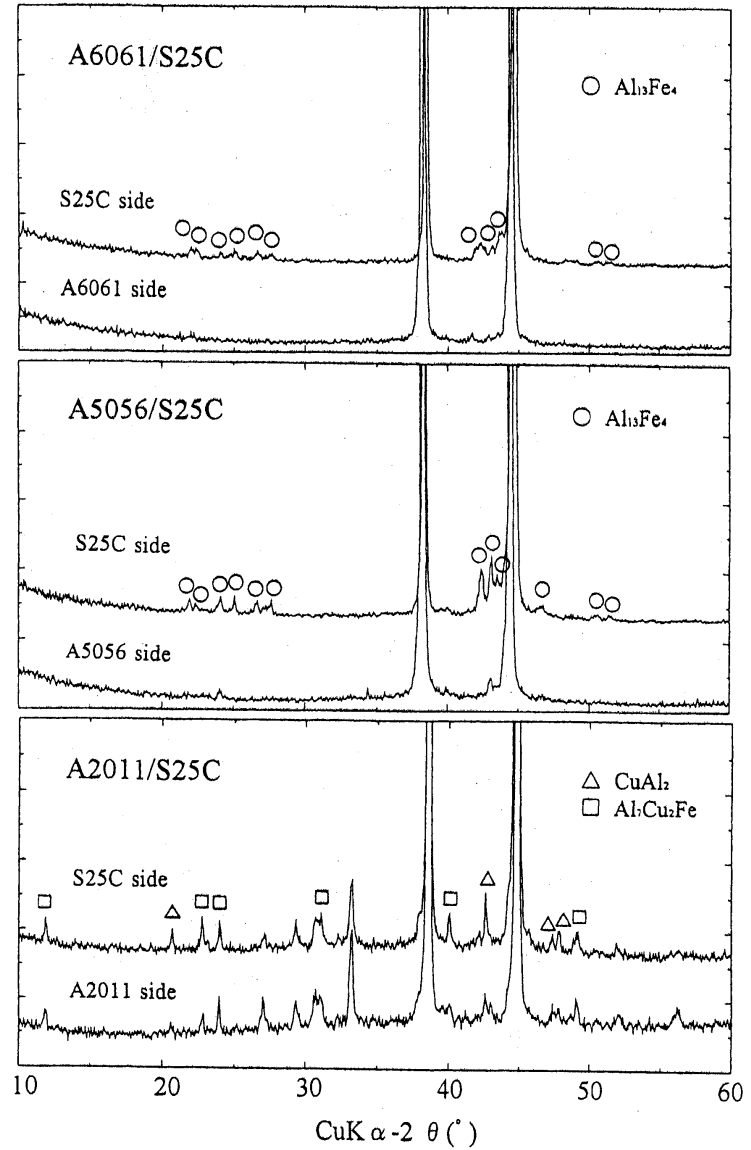

Fig. 5. X-ray diffraction patterns on friction surface of A2011/S25C, A5056/S25C and A6061/S25C. 


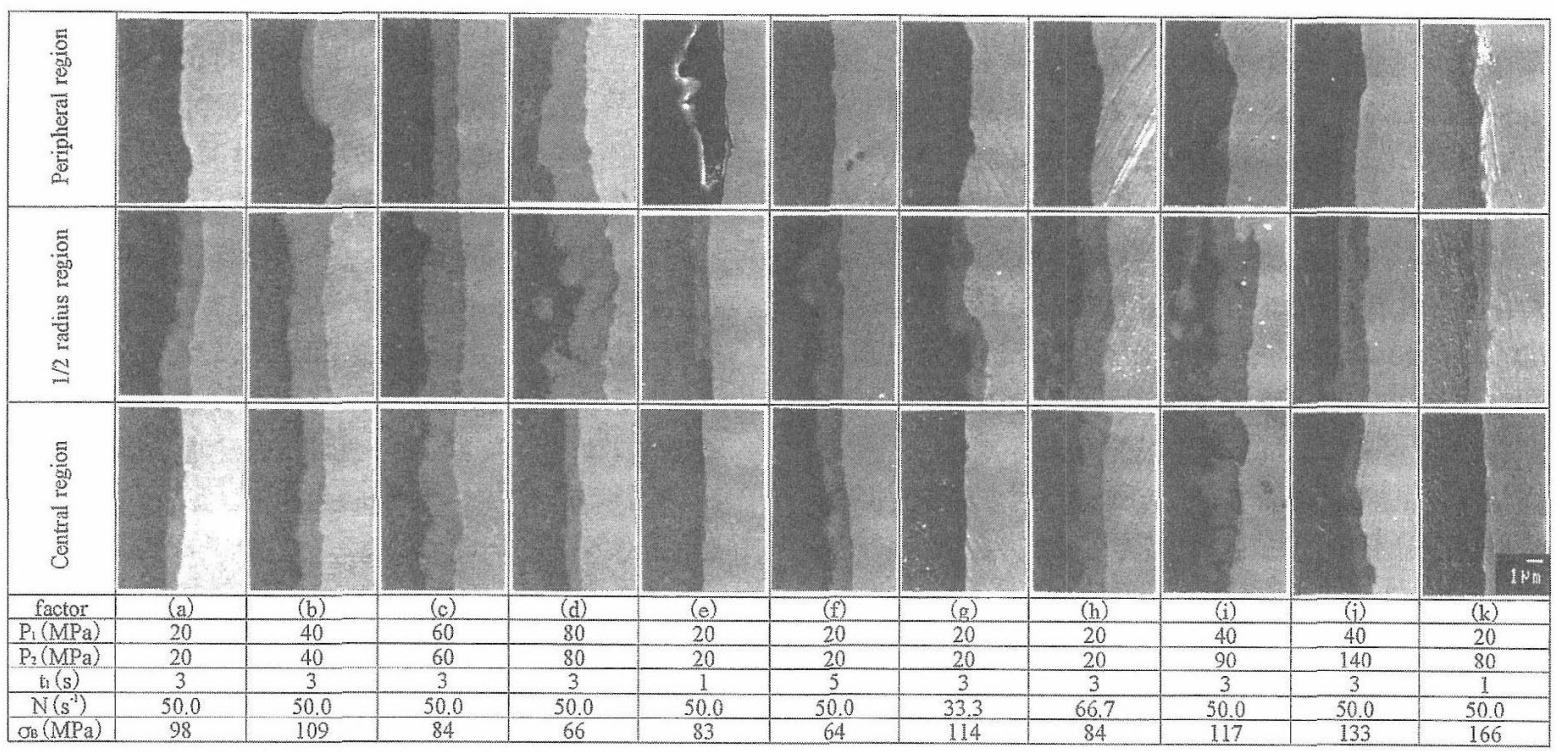

Fig. 6. SEM images of A5056/S25C weld interface.

$\mathrm{A} 6061$ の場合より強く, $\mathrm{Al}_{13} \mathrm{Fe}_{4}$ の析出量が多いことが予 想される。これら合金の主要添加元素はマグネシウムであ るが，アルミニウム合金中のマグネシウムは接合界面での 脆弱な金属間化合物層の成長を促進する作用がある3), 4) ことから，マグネシウムを含む化合物よりも Al-Fe 水化 合物の帅成が優先されたと考えられる。

一方， $\mathrm{A} 2011$ の場合には， $\mathrm{CuAl}_{2}$ 扔よび $\mathrm{Al}_{7} \mathrm{Cu}_{2} \mathrm{Fe}$ に基 づく回折線が認められる。A2011には多量の銅が添加さ れていることから，銅を含をこれらの化合物が界面に形 成されたと推測される。

\section{$3 \cdot 3$ 金属問化合物の形成状態}

3・3・1 A5056/S25C 接合界面 種々の圧接条件で 作製した継手の接合界面の SEM 像を Fig. 6 に示す。な 拈，一連のSEM写真に拈いて，いずれも左側がアルミ 二ウム合余，右側が $\mathrm{S} 25 \mathrm{C}$ である。摩擦時間 $3 \mathrm{~s}$, 回転数 $50.0 \mathrm{~s}^{-1}$ に固定して, 压力（摩擦压力就よびアプセッ卜压 力）を $20,40,60$ および $80 \mathrm{MPa}$ に変化させた場合 (Fig. 6 (a)，(b)，(c) および (d)) には, 圧力 $20 \mathrm{MPa} て ゙$ は $1 / 2$ 半径部（軸中心部から外周部方向に半径の $1 / 2$ 離 れた位置）付近で $1 \mu \mathrm{m}$ 前後の比較的均一な層が観察さ れるが，軸中心部では層は薄くなりとぎれた部分も多く 観察された。また，外周部では化合物層は認められない。 圧力が高くなるに伴い化合物層は厚くなり，圧力 $60 \mathrm{MPa}$ では界面全域で 2 ～ $3 \mu \mathrm{m}$ 程度の層が形成される。しかし ながら，圧力が $80 \mathrm{MPa}$ と高くなると中心部では逆に層は 薄くなり，また，1/2 半径部や外周部付近では A5056 と 化合物層が混在している部分も観察される。これは，高 压力を負荷するとA5056の塑性流動が激しくなり， A5056 と化合物層との界面が乱れたためと考えられる。 なおここ机らの層をEPMAにより線分析したとこう， Fig. 7 に示すように Fe-Al 系の化合物層の形成が確認で きた。

圧力 $20 \mathrm{MPa}$ ，回転数 $50.0 \mathrm{~s}^{-1}$ に固定して，摩擦時間を 1 および $5 \mathrm{~s}$ に変化させた場合（Fig. 6(e)および(f)）に

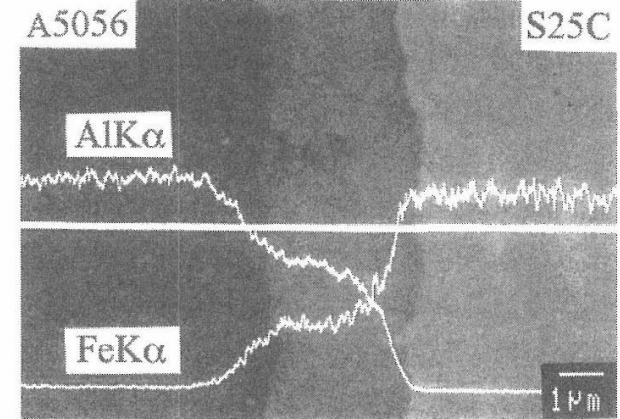

Fig. 7. EPMA line scanning profile of A5056/S25C weld interface.

は，摩擦時間 $1 \mathrm{~s} て ゙ は 1 / 2$ 半径部において部分的に薄い 層が認められるが，それ以外の場所での形成は認められ

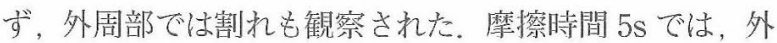
周部では層は認められないが，去れ以外の部分では1ー $2 \mu \mathrm{m}$ 程度の均一な層が形成される。摩擦時間 $3 \mathrm{~s}$ の場合 (Fig. 6 (a)）と比較すると層が厚く形成されており，また A5056 と化合物層との界面が乱机た部分も認められた。

圧力 $20 \mathrm{MPa}$ ，摩擦時間 $3 \mathrm{~s}$ に固定して，回転数を 33.3 および $66.7 \mathrm{~s}^{-1}$ に変化させた場合（Fig.6 (g) および (h)) には，回転数 $33.3 \mathrm{~s}^{-1}$ では $1 / 2$ 半径部に $1 \mu \mathrm{m}$ 以下の層が 部分的に形成されているのみであり，所々に割れが認め られた。摩擦時間 1s の場合 (Fig. 6 (e)) や回転数 $33.3 \mathrm{~s}^{-1}$ の場合には，十分な加熱が行われず発熟量が少ないため， 接合が不十分で割机が発生したと考えられる。回転数 $66.7 \mathrm{~s}^{-1}$ では，回転数 $50.0 \mathrm{~s}^{-1}$ の場合 (Fig.6 (a))よりやや 化合物が多く形成されており，1/2 半径部から軸中心部 付近で $1 \sim 2 \mu \mathrm{m}$ 程度の層が認められた。これは，回転 数が大きくなると発熱量が増加し化合物が形成されやす くなるためと考えられる。

以上の結果から，压力が増大するほじ，摩擦時㫮が長 くなるほど、そして回転数が大さくなるほど化合物は多 く形成される傾向が市る。す店わ方，入熱が大さい条件 
ほざ化合物が形成されやすいことが明らかになった。

摩擦圧力 $40 \mathrm{MPa}$, 摩擦㭙間 $3 \mathrm{~s}$, 回転数 $50.0 \mathrm{~s}^{-1}$ の状態

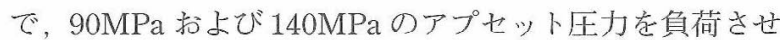
た場合（Fig. 6 (i) および (j)）には，アプセット圧力 $90 \mathrm{MPa}$ の場合の層の厚さはアプセット圧力 $40 \mathrm{MPa}$ (Fig. 6 (b)）の場合とほぼ同じかやや厚い程度であるが， A5056 と化合物層との界面は全域に就いて大きく乱れて

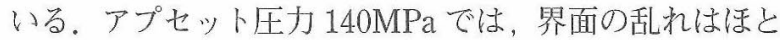
んどみられず，ほぼ全域に扎いて 1 月 m 前後の層が認めら れた。高いアプセット圧力を負荷したため，激しい塑性 流動と相手側部材となる $\mathrm{S} 25 \mathrm{C}$ との摩擦によって, 摩擦 過程で形成された化合物がはく離して薄くなったと考え られる。

最適摩擦圧接条件で压接した場合 (Fig.6 (k)) には, $1 / 2$ 半径部で $1 \mu \mathrm{m}$ 程度の層がタられたが，旮れ以外の場 所では部分的に薄い層がわずかに形成されている程度で あった。

継手の引張強さと金属間化合物の形成状態の関係につ いては，全般的に化合物層が薄く均一に形成されている 継手ほど引張強さが大きくなる傾向がお执まかに認めら れる。また，摩擦压力とアプセット圧力が同じ継手より も，摩擦圧力よりアプセット压力を大きくした継手の方 が張強さが大きい。したがって, 最適摩擦圧接条件の ように, 小さい摩擦压力で摩擦過程を経た後, 大きいア プセット压力を負荷して接合界面を十分密着させるとと もに，摩擦過程で形成された層を薄くした場合に，継手 強度が大きくなると推測される。

3・3・2 A6061/S25C 接合界面 種々の圧接条件で 作製した継手の接合界面の SEM 像を Fig. 8 に示す。摩 擦時間 $3 \mathrm{~s}$, 回転数 $50.0 \mathrm{~s}^{-1}$ の条件で, 压力を $20,40,60$ および 80MPaに変化させた場合（Fig.8 (a)，(b)，(c) および (d)）には，圧力 $20 \mathrm{MPa} て ゙ は ~ 1 / 2$ 半径部で非常 に薄い層がわずかに認められる程度であるが，圧力が高 くなるに伴って化合物層の形成範网は $1 / 2$ 半径部党中心
にして広がり，また層も厚く均一になる。しかしながら， 外周部扎上び軸中心部では化合物の形成はほとんど認め られなかった。なおこれらの層をEPMAにより線分析 したとこる，A5056の場合と同様に Fe-A1 系の化合物層 の形成が確認できた。

圧力 $20 \mathrm{MPa}$ ，回転数 $50.0 \mathrm{~s}^{-1}$ の条件で，摩擦時間を 1 および $5 \mathrm{~s}$ に変化させた場合（Fig. 8 (e) および (f)）に は，摩擦時間 1s では化合物の形成はほとんど認められな い。一方，摩擦時間 $5 \mathrm{~s}$ では，1/2 半径部において $1 \mu \mathrm{m}$ 前 後の均一な層が形成され，軸中心部でも $1 \mathrm{um}$ 以下の薄い 層が形成されており，摩擦時間 3s の場合 (Fig.8 (a)) より も化合物が多く形成されることが確認できる。

圧力 $20 \mathrm{MPa}$ ，摩擦時間 $3 \mathrm{~s}$ の条件で，回転数を 33.3 抒 よび $66.7 \mathrm{~s}^{-1}$ に変化させた場合（Fig. 8 (g)および (h)) には，回転数 $33.3 \mathrm{~s}^{-1}$ では $1 / 2$ 半径部で薄い層が部分的 に形成されているのみであった。回転数 $66.7 \mathrm{~s}^{-1}$ では， $1 / 2$ 半径部で $1 \mu \mathrm{m}$ 程度の層が比較的均一に形成されてお り，回転数の増加と共に化合物が多く形成されることが わかる。

摩擦圧力 $40 \mathrm{MPa}$ ，摩擦時間 $3 \mathrm{~s}$, 回転数 $50.0^{-1}$ の状態 で，90MPa および $140 \mathrm{MPa}$ のアプセット生力を貝荷させ た場合（Fig. 8 (i) および (j)）には，1/2半径部で $1 \mu \mathrm{m}$ 程度の薄い層が部分的に形成されているのみであり，そ の形成量はアプセット压ノの増加に伴い若干減少する傾 向がみら机た。

最適摩擦圧接条件で圧接した場合 (Fig. $8(\mathrm{k})$ ) には, $1 / 2$ 半径部で薄い層がわずかにみられた程度で，只れ以 外の場所では全く化合物は認められなかった。

継手強度に関しては, 継手 (i)，(j) 於よび (k) のように 摩擦圧力よりも大きいアプセット圧力を負荷した場合に， 引張強さは著しく大きくなる。

このように，A6061の場合には，全般的に前節の A5056 の場合に比心゙化合物の析出量は少ないものの，A5056の 場合と同様，左力が増大するほど，摩擦時間が長くなる

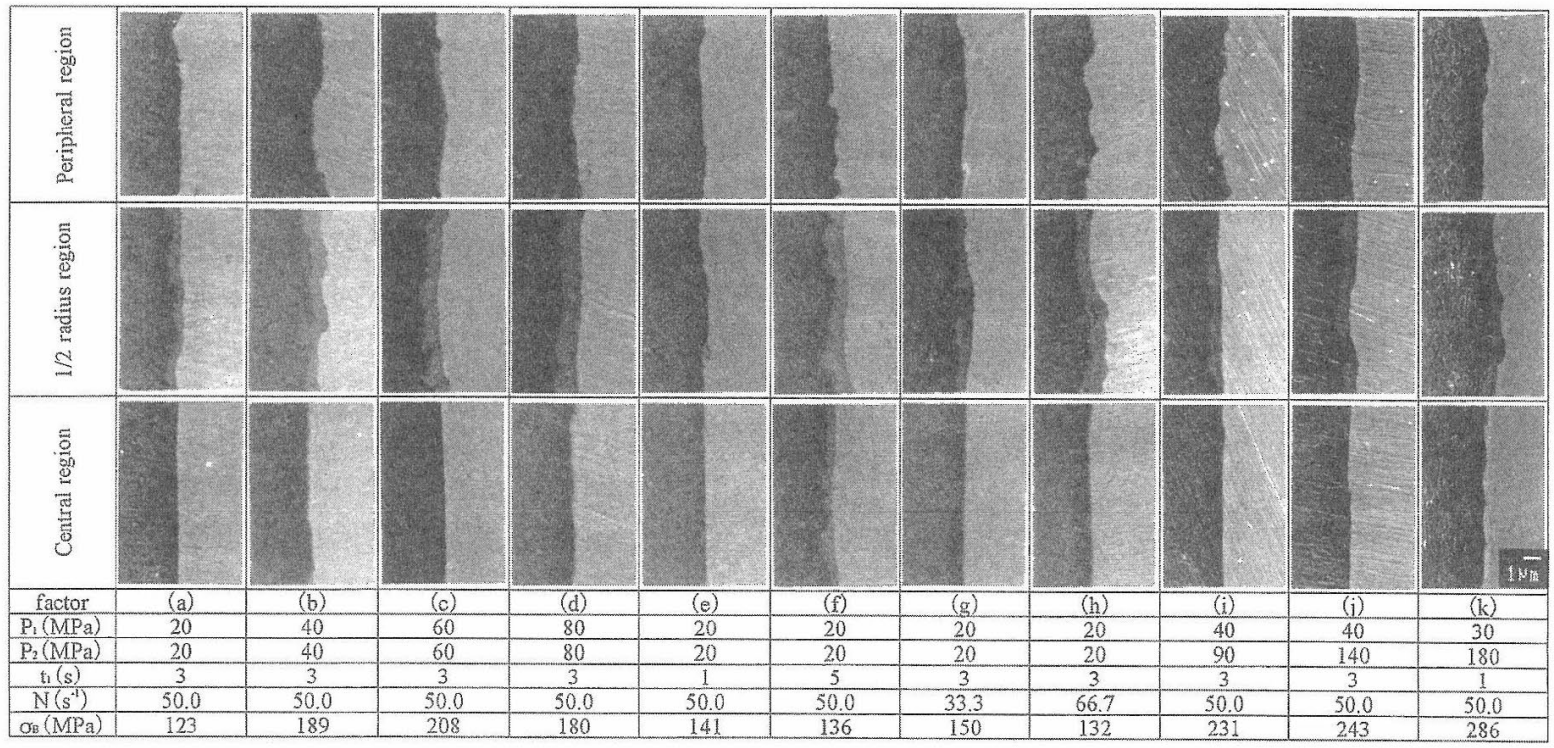

Fig. 8. SEM images of A6061/S25C weld interface. 


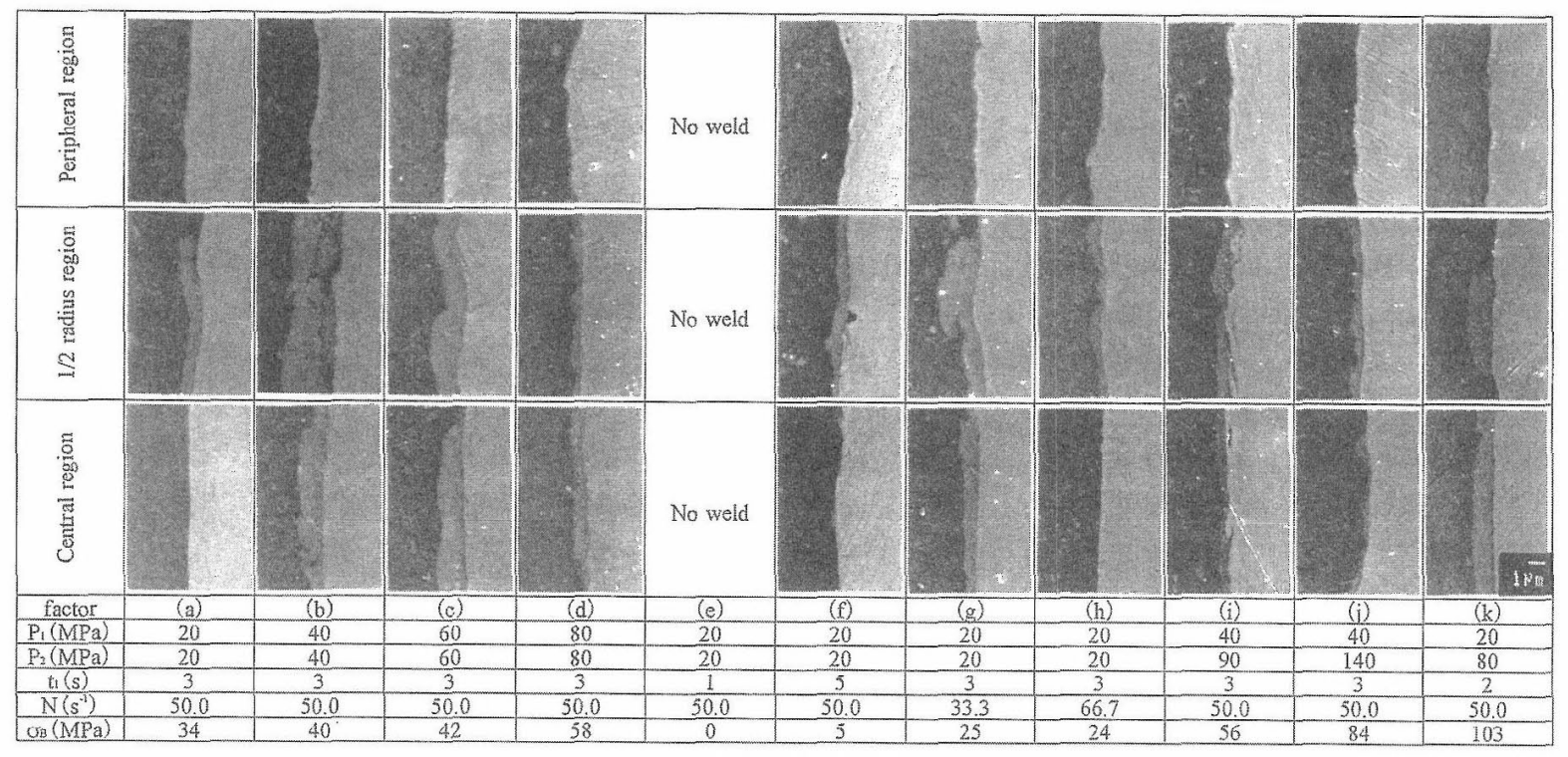

Fig. 9. SEM images of $A 2011 / S 25 C$ weld interface.

ほざ，只して回転数が大きくなるほど化合物は多く形成 される傾向がみられた。ところで，5000 系および 6000 䌽合金の主要添加元素はマグネシウムであるが，マグネ シウムにはアルミニウムの材質硬度高めて銅との物理的 接触を阻害したり，アルミニウムと鉄の拡散を促し脆弱 な化合物層を成長させる等の作用がある、1)、3，4)したがっ て，マグネシウム添加量の少ない材料の接合ではさほど 有害では無いが，マグネシウムの添加量が多くなりすぎ ると鋼との接合に悪影響を及ぼすと考えられる。このこ とから，マグネシウムの添加量が少ない 6000 系合金は， 純アルミニウムと同様に接合性は良好で专ったものと考 えられる、一方，マグネシウムの添加量が比較的多い 5000 系合金では，脆弱な化合物層が厚く形成されやすい と考光られる。乥のため，とくにマグネシウム添加量の 多いA5056 の継手では，化合物層を界面全域で薄く一様 に形成することが困難なため，接合性がやや劣る結果と なったものと推測される。

3・3・3 A2017/S25C 接合界面 種々の圧接条件で 作製した継手の接合界面のSEM 像を Fig. 9 に示す。摩 擦時間 $3 \mathrm{~s}$, 回転数 $50.0 \mathrm{~s}^{-1}$ の条件で, 摩擦圧力を 20,40 , 60 および 80MPa に変化させた場合（Fig. 9 (a)，(b)，(c) および (d)）には, 摩擦圧力 40 斿よび $60 \mathrm{MPa}$ の場合で は20MPa の場合に比べて化合物層が厚く形成されるが， $80 \mathrm{MPa}$ では逆に析出量は低下する。また，厚く形成され た化合物層内には割れが認められ (Fig. 9 (b))，非常に 脆いと推測される。これらの層をEPMAにより線分析し たところ，Fig. 10 に示すようにAl-Cu-Fe系の三元化合 物風の形成が確認できた。前述のX線回折結果からこの 三元化合物は $\mathrm{Al}_{7} \mathrm{Cu}_{2} \mathrm{Fe}$ と推定されるが, $\mathrm{Al}_{7} \mathrm{Cu}_{2} \mathrm{Fe}$ は脆く て母材との界面がはく離しやすい性質があることから5.高 圧力下では摩擦により化合物層がはく離して薄くなった と考学られる。

摩擦压力 $20 \mathrm{MPa}$, 回転数 $50.0 \mathrm{~s}^{-1}$ の条件で, 摩擦時間 を 5 s とした場合 (Fig. 9 (f) ) には，化合物層の析出状態

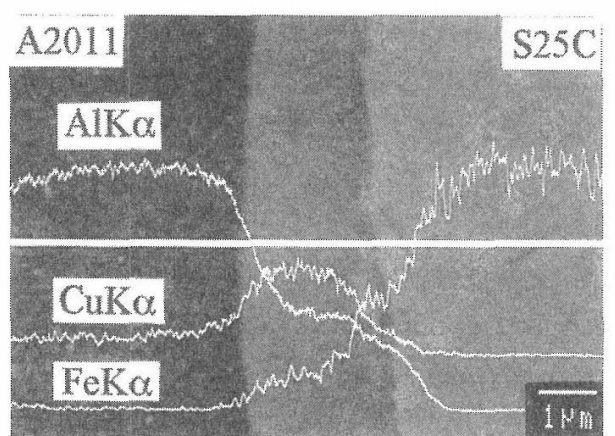

Fig. 10. EPMA line scanning profile of A2011/S25C weld interface.

は摩擦時間 3s の場合 (Fig. 9 (a)) とほぼ同程度であった。 なお，摩擦時間 $1 \mathrm{~s} の$ 条件では継手は作製できなかった。

摩擦圧力 $20 \mathrm{MPa}$, 摩擦時間 $3 \mathrm{~s}$ の条件で, 回転数 33.3 妨よび $66.7 \mathrm{~s}^{-1}$ に変化させた場合（Fig. 9 (g) および (h)）には，回転数 $33.3 \mathrm{~s}^{-1}$ では軸中心部でも部分的に 1 um 程度の層が観察され，50.0 $\mathrm{s}^{-1}$ の場合 (Fig. 9 (a)) よ りも析出量は若干多い。また, 析出量は回転数の増加と 共に減少する。乙れは，非常に脆い化合物層が高回転数 下ではく離したためと考壳られる。

摩擦圧力 $40 \mathrm{MPa}$ ，摩擦時間 $3 \mathrm{~s}$, 回転数 $50.0 \mathrm{~s}^{-1}$ の状態 で, 90MPa 於よび140MPa のアプセット圧力を負荷させ た場合（Fig. 9 (i) および (j)）には，1/2 半径部から中 心部で層が部分的に形成されているが，その析出量はア プセット压力の増加に伴い減少し、アプセット压力の負 荷により化合物層がはく離したと考えら机る。また，継 手強度はアプセット圧力の増加に伴い増大する。しかし ながら，Fig. 9 (k) に示求ように最適摩擦圧接条件での アプセット压力は $80 \mathrm{MPa}$ で晾り，学の時の化合物の析出 量は (i) および (j) の場合より多い。したがって，A2011の 場合には，大きいアプセット压力を負荷して化合物層を 薄くするここが，必ずしも継手強度の向上につながら ない。 
ところで, 純アルミニウムと銅の継手では，接合界面 に $\mathrm{Cu}-\mathrm{Al}$ 系の化合物層が形成され，これが厚くなると継 手強度は低下する。吕, 7)また， Al-Cu 系および Al-Zn-Mg$\mathrm{Cu}$ 系合金に鉄が混入すると, 脆くて母材とはく離しゃ すい $\mathrm{Al}_{7} \mathrm{Cu}_{2} \mathrm{Fe}$ 等の化合物が形成される.5)これらのことか ら，2000 系合金扔よびA7075 のように銅を多く含有す るアルミニウム合金と鋼の継手の場合には, 界面に脆い $\mathrm{Al}-\mathrm{Cu}$ 系打よび $\mathrm{Al}-\mathrm{Cu}-\mathrm{Fe}$ 系の化合物が形成されるため， 接合性が悪くなると考えられる。

以上のように, アルミニウム合金と $\mathrm{S} 25 \mathrm{C}$ との摩擦压 接性には, アルミニウム合金中の添加元素の種類と量が 大きく影響することは明らかである，すなわち，脆弱な 金属間化合物の形成を促すマグネシウムが添加された合 金の場合には，マグネシウム添加量が増加するに伴い接 合性が悪くなる傾向がみられる。これは，マグネシウム の添加量が多くなると圧接界面に $\mathrm{Al}_{13} \mathrm{Fe}_{4}$ が厚く形成さ れやすくなり，薄い化合物層を形成することが難しくな るためと考えられる。一方，銅が多く添加されたアルミ ニウム合金の場合には，界面に脆くて母相とはく離しや すい $\mathrm{Cu}-\mathrm{Al}$ 系および $\mathrm{Al}-\mathrm{Cu}-\mathrm{Fe}$ 系の化合物層が形成される ため，接合性が悪くなると考えられる.

\section{4 結 論}

9 種類のアルミニウム合金と $\mathrm{S} 25 \mathrm{C}$ 炭素鋼との摩擦圧 接を行いその接合性について検討した，さらに，接合性 の異なる 2011，5056 および 6061 アルミニウム合金と $\mathrm{S} 25 \mathrm{C}$ の圧接界面での金属間化合物の形成状態と圧接条 件との関係についても検討し, 以下の結果を得た。

(1) A1050 および 6000 系合金の場合の最大継手効率 は 90\% 以上であり接合性は良好である。 5000 系合金の場 合には, A5052 では最大継手効率は $75 \%$ で接合性は比較 的良好であるが，A5056では約 50\%で中程度の接合性と
いえる. 2000 系合金およびA7075 の場合には，最大継 手効率は $40 \%$ 以下で接合性は亜い.

(2) A5056/S25C およびA6061/S25C の接合界面には $\mathrm{Al}_{13} \mathrm{Fe}_{4}$ の金属間化合物が形成される。この層の厚さは, 圧力が増大するほど，摩擦時間が長くなるほど，そして 回転数が大きくなるほど厚くなる傾向がある．また，、 グネシウム添加量が多いA5056では，A6061 の場合に比 べ $\mathrm{Al}_{13} \mathrm{Fe}_{4}$ が多く形成される。一方, 2011/S25C の接合 界面には $\mathrm{CuAl}_{2}$ および $\mathrm{Al}_{7} \mathrm{Cu}_{2} \mathrm{Fe}$ が形成される。

(3) アルミニゥム合金と S25C との接合性は, アルミ ニウム合金中の添加元素の種類と量に大きく影響される. マグネシウムを添加した合金の場合には，添加量が多く なると $\mathrm{Al}_{13} \mathrm{Fe}_{4}$ が形成されやすくなり接合性は低下する. また，大きいアプセット压力を負荷して接合界面を十分 密着させるとともに, 摩擦過程で形成した層を薄くさせ ることにより，継手強度が向上する。一方，銅を添加し た合金の場合には，脆くて母材とはく離しやすい $\mathrm{Cu}-\mathrm{Al}$ 系 や Al-Cu-Fe 系の化合物が形成されるため接合性は悪い.

\section{参 考 文 献}

1) 例えば, S.Elliott and E.R.Wallach, Metal Const., 13, 221 (1981).

2) 川井五作, 小川恒一, 越智 秀, 時末 光, 軽金属, 49 , 83 (1999).

3 ) S. Elliott and E. R. Wallach, Metal Const., 13, 167 (1981).

4) 森井 泰, 藤田幾雄, 溶接技術, 11, 20 (1974).

5 ) 軽金属学会編, “アルミニウムの組織と性質”, p.201, p.307 (1991).

6) 仲西恒雄, 近藤一夫, 中村光雄, 米沢征寿, 溶接学会誌, 45, 1022 (1976).

7 ）諸住正太郎, 菊地迪夫, 軽金属，32，195（1982）. 